\title{
ACUTE HAEMOLYTIC ANAEMIA COMPLICATING PRIMARY ATYPICAL PNEUMONIA
}

\author{
J. Trevor Hughes, M.B., M.R.C.P.(Edin.) \\ Senior Registrar in Pathology \\ P. C. Mallam, D.M., M.R.C.P. \\ Consultant Physician
}

The Radcliffe Infirmary, Oxford

Acute haemolytic anaemia associated with high titre cold agglutinins is an uncommon complication of primary atypical pneumonia. The first description of a case appears in a paper of Clough and Richter ${ }^{4}$ recording their observations on the haemagglutinins in a patient with bronchopneumonia. In the British literature Besterman and Brigden ${ }^{2}$ first reported a case and in surveying the literature found 25 previously published cases. Since then cases have been recorded by Neely et al. ${ }^{15}$ Sigenthaler, ${ }^{16}$ Aaron $^{1}$ and by Stewart and Friedlander. ${ }^{18}$ Dacie $^{7,}{ }^{9}$ has described the serological investigation of several cases.

The condition is sufficiently rare to warrant reporting a further case with some observations on the serological findings.

\section{Case Report}

A 52-year-old taxi driver was admitted to the Radcliffe Infirmary, Oxford, on October 13, 1958, complaining of difficulty in breathing. His previous medical history was that of a chronic asthmatic whose attacks were usually controlled by an inhaler, but were occasionally more severe. He had chronic bronchitis with a cough and the production of moderate sputum.

The present illness began io days before admission with general malaise, shivering and cough with purulent sputum. He became increasingly breathless and two days before admission complained of right lower chest pain aggravated by coughing. The family and other medical history was not relevant. His general practitioner had given him a course of terramycin, beginning one week before admission. He had not had sulphonamide therapy.

\section{On Examination}

He was a distressed, ill-looking man with mild peripheral cyanosis and marked general pallor. Temperature roI. $4^{\circ} \mathrm{F}$. $\left(3^{8} .5^{\circ} \mathrm{C}\right.$. $)$.

Pulse I 44 per minute. Regular. Blood pressure 165/85. Heart sounds faint, but otherwise normal. No evidence of cardiac failure.

Barrel-shaped chest, expanding poorly. Re- spiratory rate 30 per minute with use of accessory muscles. Percussion note was hyper-resonant. Generalized harsh breath sounds with many highpitched rhonchi and some coarse crepitations at both bases.

Other systems appeared normal.

\section{Investigations}

$X$-ray chest showed increased shadowing, particularly at both bases, and signs of generalized emphysema.

Haematology. Group $\mathrm{O}$ positive, genotype DCcE. Hb 43\% (6.4 g./100 ml.). W.B.C. 24,000 per cu.mm. Blood film: red cells agglutinated and showed marked polychromasia. Normoblasts and a few proerythroblasts present. Marked neutrophil leucocytosis with small number of myelocytes. Reticulocytes $6.4 \%$. Direct Coombs test strongly positive. Cold agglutinin titre $\mathbf{I} / \mathbf{1}, 600$. Sternal marrow showed normoblastic erythroid hyperplasia. Red cell osmotic fragility was normal tested at $20^{\circ} \mathrm{C}$. and at $37^{\circ} \mathrm{C}$. Cresyl blue preparations showed no Heinz bodies.

Biochemistry. The urine contained no protein, sugar or haemoglobin and no haemosiderin crystals were seen in the centrifuged deposit. Urobilin present in slight excess of normal. Plasma bilirubin $1.4 \mathrm{mg} . / 100 \mathrm{ml}$, , blood urea $75 \mathrm{mg}$. $/ 100 \mathrm{ml}$., total serum protein $6.2 \mathrm{~g}$. $/ 100 \mathrm{ml}$. Serum electrophoresis on paper indicated an increased gamma globulin fraction.

Microbiological Investigation. Culture of sputum grew Neisseria and coliform organisms sensitive to streptomycin. Blood culture on October 14, 1958, was negative.

An examination for complement-fixing antibodies was made on paired sera dated October 22 and December 3, 1958, by Dr. Vollum. The complement fixation tests of both sera were positive at a titre of $1 / 8$ for influenza $A$, influenza $\mathrm{C}$ and mumps $\mathrm{V}$; and negative for influenza $\mathrm{B}$, psittacosis, $Q$ fever, adenovirus and sendai. The streptococcus M.G. titre of the first serum was I $/ 40$ and of the second serum. I/IO. 
Table

\begin{tabular}{|c|c|c|c|c|c|}
\hline \multirow[b]{2}{*}{ Date } & \multicolumn{2}{|c|}{$\begin{array}{l}\text { Haemo- } \\
\text { globin }\end{array}$} & \multirow{2}{*}{$\begin{array}{c}\text { Reticulo- } \\
\text { cytes } \\
\%\end{array}$} & \multirow{2}{*}{$\begin{array}{c}\text { Cold } \\
\text { Agglu- } \\
\text { tinin } \\
\text { Titre } \\
\text { at } 4^{\circ} \mathrm{C} \text {. }\end{array}$} & \multirow{2}{*}{$\begin{array}{c}\text { Titre } \\
\text { of } \\
\text { Direct } \\
\text { Coombs } \\
\text { Test }\end{array}$} \\
\hline & $\%$ & $\begin{array}{l}\text { G. per } \\
\text { roo } \\
\text { ml. }\end{array}$ & & & \\
\hline $14 \cdot 10.5^{8}$ & 43 & 6.4 & & $1 / 1,600$ & $1 / 160$ \\
\hline I $5.10 .5^{8}$ & 37 & $5 \cdot 5$ & & & \\
\hline I6.10.58 & 48 & 7.1 & 7.0 & $\because$ & $\therefore$ \\
\hline 22.10 .58 & 55 & 81 & & $1 / 320$ & $1 / 40^{\circ}$ \\
\hline r.11. $5^{8}$ & 78 & II.5 & 4.4 & $\therefore$ & \\
\hline 4.11 .58 & 79 & 11.7 & $\therefore$ & $1 / 64$ & $1 / 40$ \\
\hline 3.12 .58 & IIo & $1 \overline{6} .3$ & 0.8 & $x / 64$ & $1 / 20$ \\
\hline $31.12 .5^{8}$ & & & & $1 / 16$ & Negative \\
\hline 28.1 .59 & & & & $1 / 2$ & Negative \\
\hline
\end{tabular}

\section{Treatment and Subsequent Progress}

The table summarizes the haematological changes. The patient was kept warm to the point of discomfort. Penicillin therapy. was begun after a negative intradermal test for sensitivity, of which there was a doubtful history. Thirty-six hours after admission his haemoglobin had dropped to $37 \%$ (5.5 g./100 ml.). On October 16, 1958, he was transfused with packed cells from 4 pints of group $O$ positive stored blood. Recently bled donor blood was selected and the lengthened tubing of the giving set warmed to $37^{\circ} \mathrm{C}$. in a water bath. Some difficulty was experienced in crossmatching blood. All donor red cells tested were incompatible at room temperature. The cells were compatible by the indirect Coombs test, providing precautions were taken to prevent the temperature falling below $37^{\circ} \mathrm{C}$. during incubation and washing of the cells. The transfusion produced no reaction and the haemoglobin rose to $48 \%$ (7.1 g./100 ml.).

The mild pyrexia responded to a five-day course of streptomycin, I g. daily; a second course later became necessary and was also effective. Ferrous gluconate, gr. 5, three times a day was given. His general condition improved steadily and he was discharged from hospital on November I I, $195^{8}$, after a stay of nearly five weeks.

When seen at out-patients on December 3, 1958, the improvement had been maintained. The haemoglobin was $110 \%$ (16.3 g./100 ml.). Reticulocytes $0.8 \%$, W.B.C. 1 I, 800 per cu.mm. Film showed slight eosinophilia. The direct Coombs test was weakly positive, titre $\mathrm{r} / 20$. Cold agglutinins present to a titre of $x / 64$.
At a further attendance on December $31 ; 1958$, the direct Coombs test was negative and the cold agglutinin titre had fallen to $1 / 16$. On ianuary 28 , 1959, the direct Coombs test was negative and the cold agglutinin titre was $\mathbf{I} / 2$.

\section{Serological Observations \\ Direct Coombs Tests}

The direct Coombs test was positive to a titre of $1 / 160$ on October 14, 1958, and was not inhibited by gamma globulin. The further observations on the direct Coombs test are given in the table. It is interesting that the direct Coombs test was still weakly positive on December 3,1958 , when the haemoglobin was $100 \%$ and the haemolytic episode over.

An eluate made by Kidd's method ${ }^{13}$ showed no activity either at $20^{\circ} \mathrm{C}$. or $37^{\circ} \mathrm{C}$. or by indirect Coombs test. A cold non-specific saline agglutinating antibody was recovered from cells sensitized with the patient's serum at $4^{\circ} \mathrm{C}$. and warmed to $.37^{\circ} \mathrm{C}$.

\section{Haemagglutinins}

The serum (October 22, 1958) contained cold auto- and isohaemagglutinins having the following thermal range:

$$
\begin{array}{rlll}
4^{\circ} \mathrm{C} . & \ldots & \ldots & \mathbf{1} / 320 \\
12^{\circ} \mathrm{C} . & \ldots & \ldots & \mathbf{1} / \mathbf{1 2 8} \\
20^{\circ} \mathrm{C} . & \ldots & \ldots & \mathbf{1} / 64 \\
31^{\circ} \mathrm{C} . & \ldots & \ldots & \mathbf{1} / 8 \\
37^{\circ} \mathrm{C} . & \ldots & \ldots & \text { No agglutination }
\end{array}
$$

No agglutination was obtained with cells by indirect Coombs test at $37^{\circ} \mathrm{C}$. or with papainized cells at $37^{\circ} \mathrm{C}$. The serum showed no difference in the agglutinability of human red cells, as is shown by the high titre cold antibodies of acquired haemolytic anaemia. ${ }^{6}$

\section{Haemolysins}

Cold haemolysin was demonstrated by the method described by Dacie. ${ }^{10}$ Traces of haemolysin were observed with unacidified patient's serum and frank haemolysis with acidified serum was detectable after 30 minutes.

\section{Absorption of Haemagglutinins}

The cold agglutinins proved difficult to absorb with the patient's own cells. Absorption was carried out three times at $4^{\circ} \mathrm{C}$., in each case using an equal volume of patient's own cells washed at $37^{\circ} \mathrm{C}$. The titre of agglutination was diminished to r/8. This effect was equivalent to a single similar absorption with normal cells and three such absorptions removed all but traces of agglutinins. 
The absorption procedure with the patient's own cells caused some haemolysis.

\section{Discussion}

The case described is an example of moderate severity of this complication of acute virus pneumonia.

The haemolytic episode was fully manifest on admission to hospital Io days after the onset of respiratory symptoms. The blood picture showed the profound disturbance caused by the haemolysis, whilst the serological findings of high titre cold agglutinins, cold haemolysin and positive direct Coombs test were typical.

The absence of haemoglobinuria was unusual, as was the normal red cell osmotic fragility.

\section{Aetiology}

This remains obscure, as does the primary cause of idiopathic acquired haemolytic anaemia. It seems now evident that there is no causal relationship with sulphonamide therapy. Earlier reports, for example, Dameshek, ${ }^{11}$ emphasized this association. It is possible that virus particles may be fixed to red cells, rendering the latter susceptible to the action of virus antibodies. This has been suggested by Moolten et al. ${ }^{14}$ who have recovered the virus of Newcastle disease from the blood of patients suffering from an acquired haemolytic anaemia. Betke et $a .^{3}$ have isolated Coxsackie A virus from the faeces of a boy suffering from acute haemolytic anaemia and Dacie ${ }^{8}$ has recorded acute haemolytic anaemia following an attack of measles.

\section{Mechanism of Haemolysis}

Apart from the possible effect of a virus, several explanations have been put forward to explain the haemolysis. Stats ${ }^{17}$ showed that red cells agglutinated by cold agglutinins were very susceptible to mechanical trauma and the case of Colmers and Snavely ${ }^{5}$ showed the injurious effect of sponging with cold alcohol in a case with high titre cold agglutinins. Dacie ${ }^{9}$ has described his finding of a haemolysin best demonstrated by acidification of the patient's serum. A similar haemolysin was demonstrated in the case described here. The case of Stewart and Friedlander ${ }^{18}$ showed a correlation between the thermal range of the haemolysin and the clinical evidence of the in vivo haemolysis.

\section{Diagnosis}

The onset of symptoms and signs of anaemia during the second or third week of a respiratory infection should arouse suspicion of acute haemolytic anaemia. Confirmation may be sought in the blood changes, which, in addition to a fall in haemoglobin, include reticulocytosis and neutro- phil leucocytosis. The blood film will show polychromasia and may show normoblasts and myelocytes. Haemoglobinuria may be present. The direct Coombs test will be positive and the serum will contain cold haemagglutinins in high titre. Finland et al. ${ }^{12}$ found significant titres of cold agglutinins in infectious disease only in primary atypical pneumonia and in mumps.

\section{Treatment}

The management of the case may cause concern, but the ultimate prognosis is good. The patient should be kept warm. Transfusion should be given only if the anaemia is severe. Crossmatching of blood may be difficult. Fresh blood is desirable and should be given at $37^{\circ} \mathrm{C}$. Dacie ${ }^{10}$ does not recommend splenectomy and considers that ACTH or cortisone should only rarely be required.

\section{Summary}

A case of haemolytic anaemia complicating atypical primary pneumonia is described. Initially the serum contained non-specific cold agglutinins in a titre of $\mathrm{r} / \mathrm{I}, 600$, though the titre fell rapidly. The positive direct Coombs test was of the nongamma-globulin type, being not inhibited by gamma-globulin. Treatment was by blood transfusion, after which steady improvement occurred. The aetiology and mechanism of the haemolysis are discussed and some remarks are made on diagnosis and treatment.

It is a pleasure to record our thanks to Dr. M. M. Pickles for her help and encouragement in the preparation of this report.

\section{REFERENCES}

1. AARON, R. S. (1952), Arch. intern. Med., 89, 293.

2. BES'TERMAN, E., and BRIGDEN, W. (1949), Thorax, 4, I 34.

3. BETKE, K., RICHARZ, H., SCHUBOTHE, H., and VIVELL, O. (1953), Klin. Wschr., 31, 373.

4. CLOUGH, M. C., and RICHTER, I. M. (1918), Bull. Fohns Hopk. Hosp., 29, 86.

5. COLMERS, R. A., and SNAVELY, J. G. (1947), Neqi Engl. 7. Med., 237, 505 .

6. CROOKSTON, J. H., DACIE. J. V., and ROSSI, V. (1956), Brit. F. Haemat., 2, $32 \mathrm{r}$.

7. DACIE, J. V. (1950), F. Path. Bact., 62, 24 I.

8. DACIE, J. V. (r954), 'The Haemolytic Anaemias', J. \& A. Churchill, London.

9. DACIE, J. V. (1955), Proc. rov. Soc. Med., 48, 211.

ı. DACIE, J. V. (1956), 'Practical Haematology', 2nd edition, J. \& A. Churchili, London.

I I. DAMESHEK, W. (r 943), F. Amer. med. Ass., 123, 77.

12. FINLAND, M., PETERSON, O. L., ALLEN, H. E., SAMPER, B. A., and BARNES, M.W. (1945), F. clin. Invest., $24,45 \mathrm{I}$.

13. KIDD, P. (1949), f. clin. Path., 2, 103

4. MOOLTEN, S. E., CLARK, E., GLASSER, B. F., KA'TZ, F., and MILLER, B. S. (1953), Amer. F. Med., 14, 294.

I 5. NEELY, F. L., BARIA, W. H. SMITH, C., and STONE, C. F. (1951), 7. Lab. clin. Med., 37, 382 .

16. SIEGENTHALER, W. (1952), Schweiz. med. Wschr., 82, 1 100.

17. STATS, D. (1945), F. clin. Invest., 24, 33.

8. STEWART, J. W., and FRIEDLANDER, P. H. (.957), Larcet, ii, 774 . 